\title{
ON A NEW PLANKTOBENTHIC SCOLECITHRICID COPEPOD (CALANOIDA, CRUSTACEA) FROM THE BRAZILIAN CONTINENTAL SHELF
}

\author{
A.F. Campaner \\ Inst. Oceanográfico, Univ. S. Paulo - Brasil
}

\begin{abstract}
RESUMO brasileira"

"Sobre um novo copépodo scolecitricídeo (Calanoida, Crustacea) da plataforma continental

Descreve-se neste trabalho o copépodo planctobentônico "Scolecithricella" pseudoculato sp. n. e sua posição genérica é discutida.
\end{abstract}

\section{ABSTRACT}

The planktobenthic copepod "Scolecithricella" pseudoculata sp. $\mathrm{n}$. is described in this paper and its generic status is discussed.

\section{INTRODUCTION}

During the study of 21 plankton samples collected close to the bottom of the Brazilian continental shelf, I had the oportunity of finding and describing some new species of planktobenthic copepods from the families Arietellidae (Campaner, 1977), Aetideidae / Phaennidae (Campaner, 1978) and, now, Scolecithricidae.

This family and some of its genera were more recently redefined by Bardford (1973), who separated four groups of scolecithricid species possibly representing unnamed genera. Some species of one of these groups and other redefined and new described species were placed by Roe (1975) within the new genus Scopalatum.

The scolecithricid copepod to be described here does not belong to any of the known genera from this family, but it may be included in Bradford's (1973: 146) "Scolecithrix" ctenopus group, after some modifications and additions to its definition. 
As I have no possibility of redefining the species which are certainly congeneric with the one to be described, I decided to place it in the genus Scolecithricella until its correct genus is erected.

\section{SYSTEMATICS}

\section{“SCOLECITHRICELLA" PSEUDOCULATA SP. N.}

Material and locality - One adult female $(1.71 \mathrm{~mm}$ long) from a plankton-net haul adapted to a special dredge, taken from a depth of $100 \mathrm{~m}$, in $11.67^{\circ} \mathrm{C}$ temperature and $34.92 \mathrm{o} / \mathrm{oo}$ salinity, over the Brazilian continental shelf $\left(23019^{\prime} \mathrm{S}, 41057^{\circ} \mathrm{W}\right)$ at 21:30 o'clock by Dr. Plínio Soares Moreira from the R/V "Prof. W Besnard" on the 3rd September 1970.

This specimen (holotype) is deposited under ref. no 4381 at the "Museu de Zoologia - Univ. S. Paulo" (MZ USP).

\section{Description of the female - Figs. 1-17}

The body (Figs. 1-2) is $1.71 \mathrm{~mm}$ long, with the head and the lst thoracic segment (Thl) united; the Th2 to Th5 are free segments and the Th5 is laterally produced, almost reaching the distal part of the genital segment and ending in 1 subterminal rounded and 1 terminal acute points (Fig. 4). The abdomen is 4 -segmented (Ab4 strongly reduced).

The antennule (Fig. 5) has 24 free joints and overreaches the length of the body. The antenna (Fig. 6) has the exopodite ( $R e$ ) longer than the endopodite (Ri).

The mouth region, in lateral view, is shown by the Fig. 7. The Re of the mandibular palp (Fig. 8) was lost and the cuttingedge of the gnathobase is shown in the Fig. 9.

The number of setae of the Lil (1st inner lobe): Li2:Li3 B 2 (2nd basipodite):Ril: Ri2 + 3:Re:Lel (lst outer lobe) of the maxillule (Fig. 10) are respectively 11:2:2:4:2: $5: 7: 9$. One of the setae of the Lil is on its posterior surface.

The five inner lobes (Lil to Li5) of the basipodites of the maxilla (Fig. 11) have the following number of setae respectively 3:3:2:3:4 (one of these is a vermiform seta). The Ri has 5 brush-like and 3 fleshy and flattened vermiform setae, as shown by the Fig. 11 .

The maxillipede (Fig. 12) has 3 terminal plumose, 2 nude, 2 vermiform and 1 minute proximal setae plus some proximal setules on the B1; the B2 has 3 median placed and 2 terminal setae, the 5 joints of the Ri (Ril to Ri5) have the following number of setae $=4: 4: 3: 4: 4$.

The 1st leg - PI - (Fig. 13) has a 1-jointed Ri and a 3-jointed Re. The outer spiniform seta of the Rel overreaches the length of the Re2. Unfortunately the Ri and/or the Re of the P2 (Fig. 14), P3 (Fig. 15) and P4 (Fig. 16) are incomplete.

The P5 (Fig. 17) is uniramous and 3-jointed (although the 2nd and 3rd joints are not completely separated dorsally). The last joint has one strong and spinulose marginal spine, two short apical and many other widely distributed spines. 

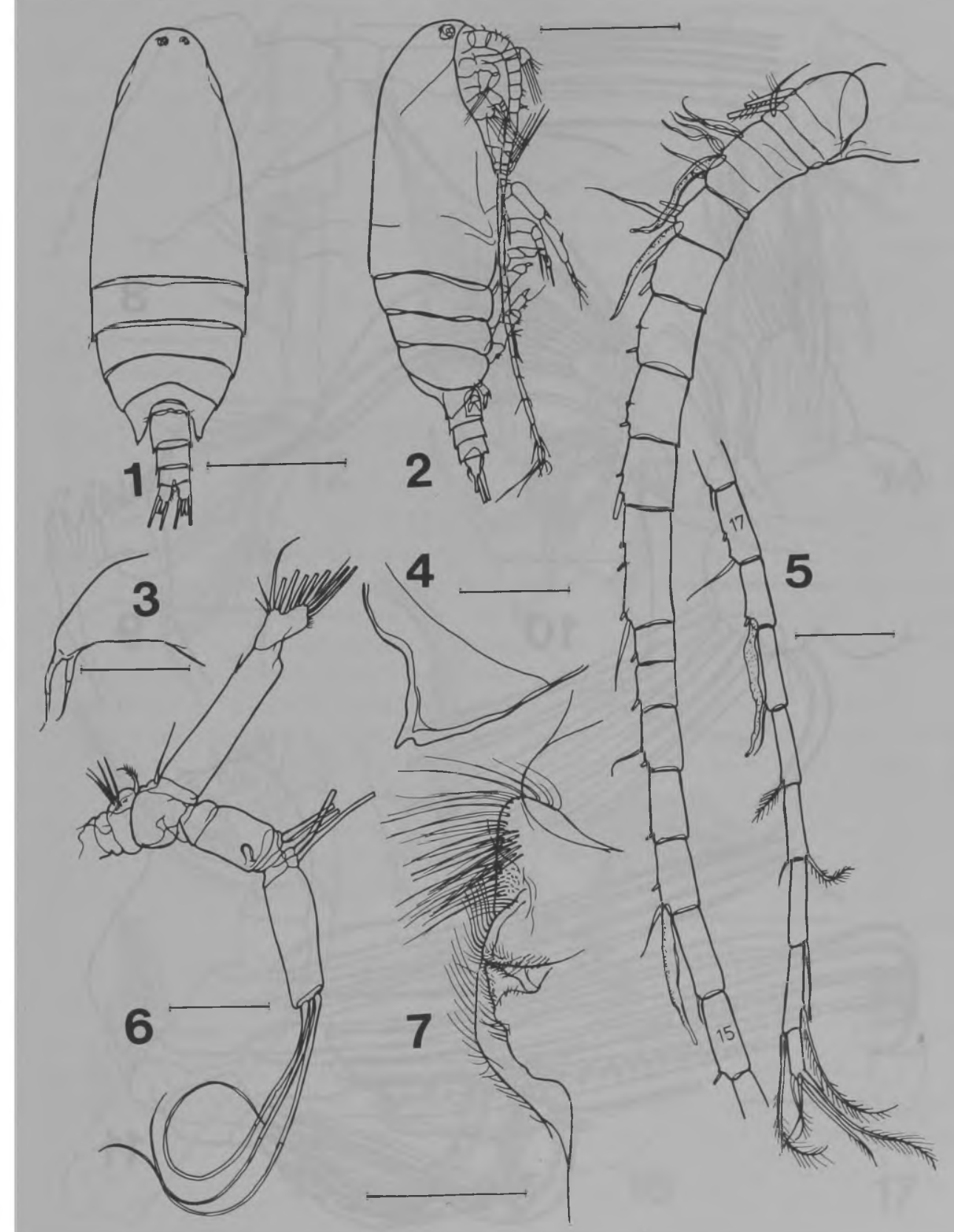

"Scolecithricella" pseudoculata sp. n., adult female (holotype) - Figs. 1 - Total, dorsal view; 2 - Total, profile; 3 Rostrum, lateral view; 4 Distal part of the last thoracic segment (Th5), lateral view; 5 Antennule; 6 Antenna; 7 Mouth region, lateral view. Scales: Figs. $1-2=0,5 \mathrm{~mm}$ and Figs. $37=$ $0,1 \mathrm{~mm}$. 


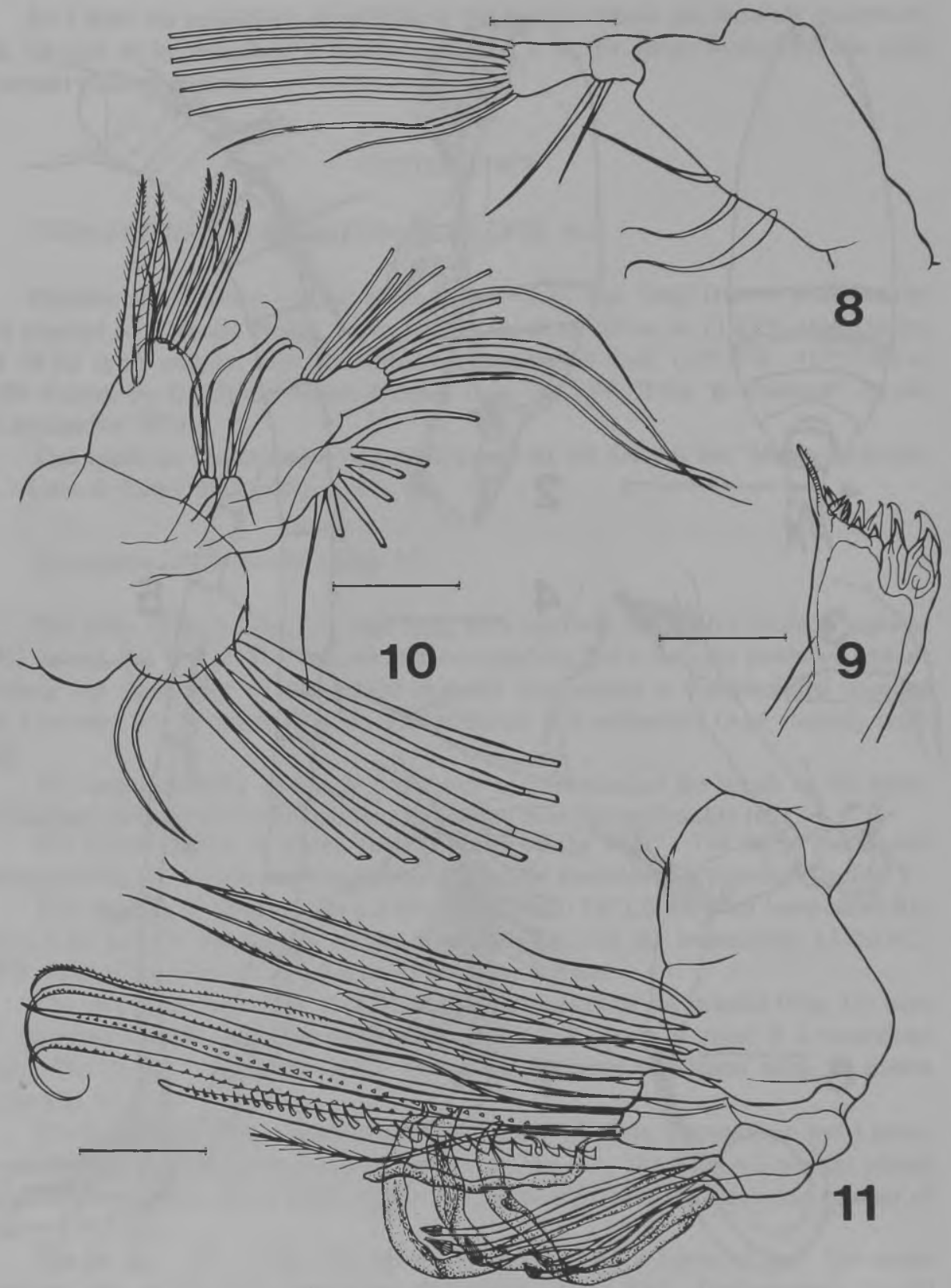

"Scolecithricella" pseudoculata sp. n., adult female (holotype) Figs. 8 Mandibular palp; 9 Mandibular gnathobase; 10 - Maxillule; 11 - Maxilla. Scale $=0,05 \mathrm{~mm}$. 

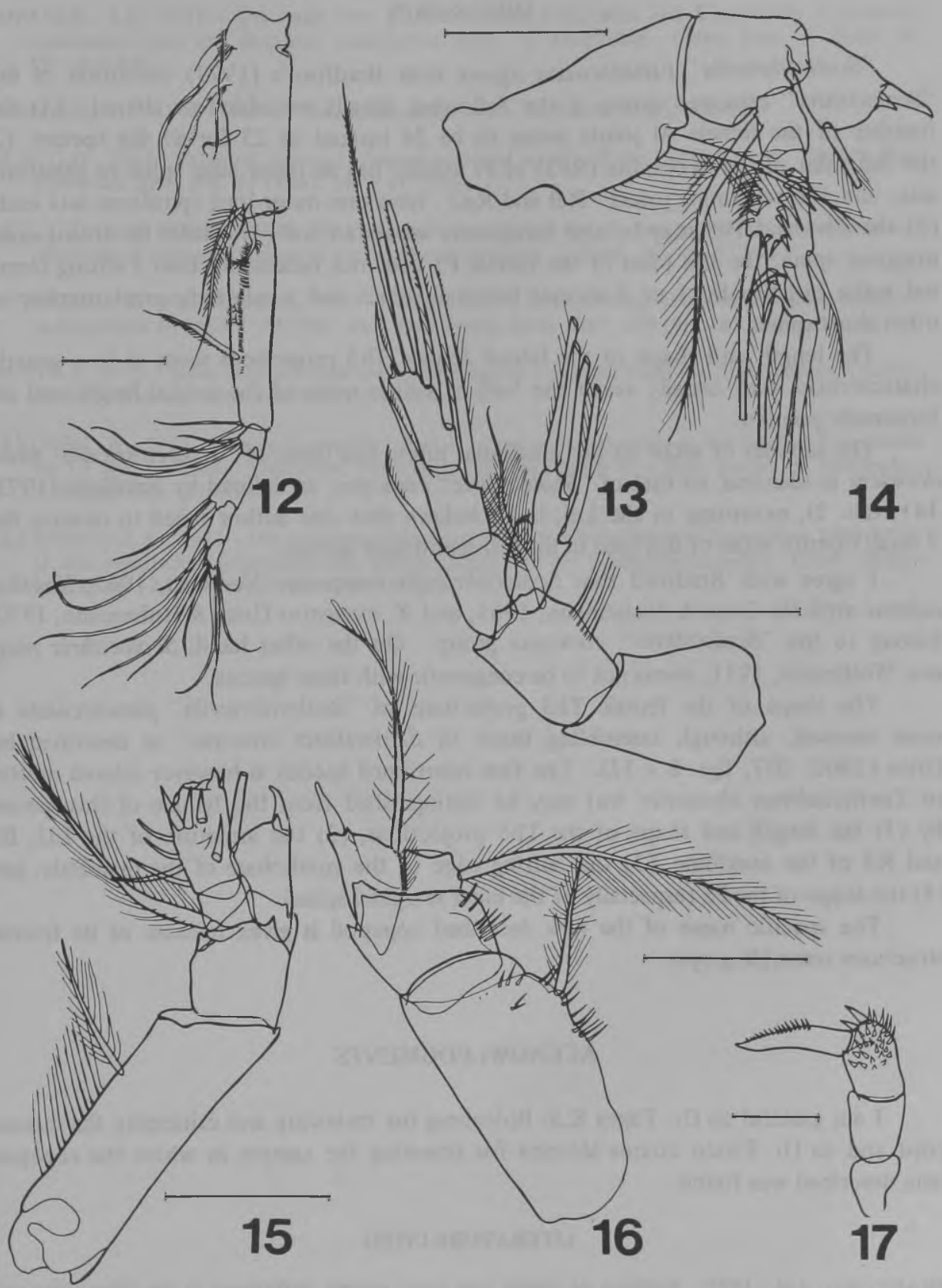

14
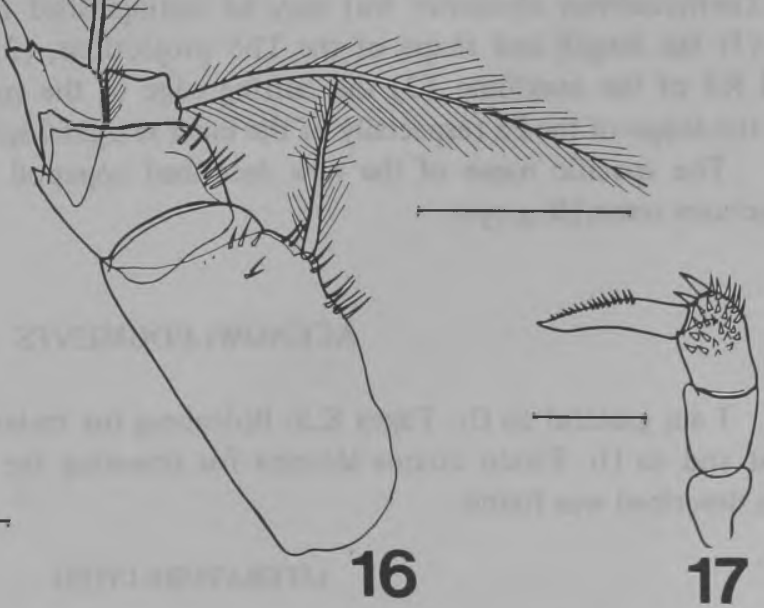

"Scolecithricella" pseudoculata sp. n., adult female (holotype) Figs. 12 Maxillipede; 13 1st leg (P1); 14 2nd leg (P2); 15 3rd leg (P3); 16 4th leg (P4); 17 Right 5th leg (P5), ventral side. Scales: Figs. $12-16=0,1 \mathrm{~mm}$, Fig. $17=0,05 \mathrm{~mm}$. 


\section{DISCUSSION}

"Scolecithricella" pseudoculata agrees with Bradford's (1973) definition of the "Scolecithrix" ctenopus group if the following details are added or altered: (1) the number of the female $\mathrm{Al}$ joints seems to be 24 instead of 23 for all the species, (2) the last joint of the exopodite (Re3) of Pl usually has an outer edge spine or spiniform seta, and the remaining joints Rel and $\mathrm{Re} 2$ have one outer long spiniform seta each, (3) the Th4 and Th5 may be also completely separated and (4) besides the strong inner marginal spine, the last joint of the female P5 does not necessarily bear a strong terminal spine but usually 1 or 2 shorter terminal spines and a relatively great number of other short spines.

The length and shape of the lateral female Th5 projections seem to be a generic characteristic, they usually reach the half or a little more of the genital length and are terminally pointed.

The number of setae on the maxillular joints and lobes of "Scolecithricella" pseudoculata is identical to that of "Scolecithrix" ctenopus, as defined by Bradford (1973: 141, tab. 2), excepting in the Lel, but I believe that this author failed to observe the 2 small inferior setae of this lobe in the last mentioned species.

I agree with Bradford that Scolecithricella marquesae Vervoort, 1965, Xanthocalanus difficilis Grice \& Hulsemann, 1965, and X. elongatus Grice \& Hulsemann, 1970, belong to the "Scolecithrix" ctenopus group. On the other hand, Scolecithrix magnus, Wolfenden, 1911, seems not to be congeneric with these species.

The shape of the female Th5 projections of "Scolecithricella" pseudoculata is most unusual, although resembling those of Scolecithrix ctenopus, as described by Grice (1962: 207. figs. 8 12). The first mentioned species is however related mostly to Xanthocalanus elongatus, but may be distinguished from the female of this species by (1) the length and shape of the Th5 projections, (2) the armature of the Li3, B2 and Ril of the maxillule, (3) the cutting edge of the gnathobase of the mandible, and (4) the shape of the P5 (especially of the inner marginal spine).

The specific name of the new described copepod is given because of its frontal structures resembling eyes.

\section{ACKNOWLEDGMENTS}

I am grateful to Dr. Tagea K.S. Björnberg for reviewing and criticizing the manuscript and to Dr. Plínio Soares Moreira for donating the sample in which the copepod here described was found.

\section{LITERATURE CITED}

BRADFORD, J.M., 1973 Revision of family and some generic definitions in the Phaennidae and Scolecithricidae. (Copepoda: Calanoida). N.Z. Jl. mar. Freshwat. Res. 7 (1\& 2): 133-152.

CAMPANER, A.F., 1977 New definition of the Arietellidae (Copepoda, Calanoida), with the description of a new genus and species, and separation of the Phyllopidae fam. n. Ciēnc.

Cult., S. Paulo 29 (7): 811-818. 
CAMPANER, A.F. 1978 On some new planktobenthic Aetideidae and Phaennidae (Copepoda, Calanoida) from the Brazilian continental shelf. I. Aetideidae. Ciênc. Cult., S. Paulo, 30 (7): 863-876.

CAMpaner, A. F 1978 - Ibid. II. Phaennidae. Ciên. Cult., S. Paulo, 30 (8): 966-982.

GRICE, G.D., 1962 Calanoid copepods from Equatorial waters of the Pacific Ocean. Fishery Bull. Fish Wildl. Serv. U.S. 61 (186): i-iv + 171-246.

GRICE, G.D. \& K. HULSEMANN, 1965 - Abundance, vertical distribution and taxonomy of calanoid copepods at selected stations in the Northeast Atlantic. J. Zool. 146 (2): 213-262.

GRICE, G.D. \& K. HULSEMANN, 1970 New species of bottom-living calanoid copepods collected in deepwater by DSRV' ALVIN. Bull. Mus. comp. Zool. Harv. 139 (4): 185-230.

ROE, H.S.J., 1975 Some new and rare species of calanoid copepods from the Northeastern Atlantic. Bull. Br. Mus. nat. Hist. (Zool.) 28 (7): 295-372.

VERVOORT, W., 1965 Pelagic Copepoda. Part II - Copepoda Calanoida of the families Phaennidae up to and including Acartiidae, containing the description of a new species of Aetideidae. Atlantide Rep. (8): 9-216.

WOLFENDEN, R.N., 1911 Die marinen Copepoden der Deutschen Südpolar Expedition 1901-1903. II. Die pelagischen Copepoden der Westwinddrift und des Südlichen Eismeers. Dtsch. Südpolar-Exped. 12, Zool. 4 (2): 181-380 + 20 pls. 
